\title{
Fungsi Labai dalam Upacara Kematian di Nagari Sungai Durian
}

\author{
Diah Saputri', Erda Fitriani ${ }^{2}$ \\ 1,2Universitas Negeri Padang \\ email: diahputri2080@gmail.com, erda cim@yahoo.com
}

\begin{abstract}
Abstrak
Penelitian ini bertujuan untuk untuk menjelaskan fungsi labai dalam upacara kematian di Nagari Sungai Durian. Penelitian ini dianalisis dengan menggunakan teoriStruktural Fungsional RadcliffeBrown. Penelitian ini menggunakan pendekatan kualitatif dengan tipe etnografi. Pemilihan informan dilakukan secara purposive sampling dengan jumlah informan 24 orang. Pengumpulan data dilakukan dengan cara observasi partisipasi aktif, wawancara mendalam dan dokumentasi. Dari hasil penelitian dapat disimpulkan bahwa labai berfungsi dalam upacara kematian bagi masyarakat Sungai Durian. Fungsi tersebut bertujuan untuk menjaga/membina struktur atau kesesuaian antara kegiatan dan kebutuhan dari struktur sosial masyarakat Sungai Durian. Fungsi labai dalam upacara kematian di Sungai Durian yaitu a) labai nagari; memimpin proses mancabiak kain kafan, memimpin proses pemandian jenazah, mambuang aie sambilan, mengafani jenazah, memandu pemakaman jenazah. b) labai suku; menyampaiakan pesan duka kepada labai nagari, menyambut labai, membantu labai nagari mancabiak kain kafan, memberi kata pembuka tahlie, memandu proses pemakaman, manalakin manimpo, Manalakin tujuah hari, memberi kata pembuka dalam maniigo hari, manujuah hari, maampek puluah hari dan manyaratuih hari.
\end{abstract}

Kata Kunci: Labai, Upacara Kematian, Fungsi, Stuktur Sosial

\begin{abstract}
This study aims to explain the function of labai in a death ceremony in Nagari Sungai Durian. This research was analyzed using Radcliff-Brown's. This study uses a qualitative approach to the type of ethnographic study research. The selection of informants was done by purposive sampling with the number of informants 24 people. Data collection is done by observation of active participation, indepth interviews, documentation, and data validity carried out by data triangulation. The data obtained were analyzed using Radcliff Brown's Functional Structural analysis. From the results of the study it can be concluded that labai functions in the death ceremony for the Durian River community. The function aims to maintain / foster the structure or compatibility between the effects of activities and the needs of the social structure of the Durian River community. That role was called by Radcliffe Brown as a function. The function is seen in emic, namely: conveying the message of sorrow, mancabiak of the shroud, bathing the corpse, throwing aie aside, forgiving the corpse, praying the corpse, burying the corpse, welcoming labai, helping labai nagari mancabiak the shroud, opening tahlie and doing petitih, manalakin manimpo, Manalakin is seven days old and determines who will be taken in carrying out the death ceremony.
\end{abstract}

Keywords: Labai, Death Ceremony, Function, social structure. 


\section{Pendahuluan}

Kepemimpinan adalah suatu kedudukan sosial dan proses sosial masyarakat. Kedudukan seorang pemimpin membawa sejumlah hak dan kewajiban untuk mengatur masyarakatnya. Di Minangkabau, setiap nagari memiliki sistem kepemimpinan yang sudah diwarisi secara turun temurun, pemilihan seseorang yang akan menjadi pemimpin dilakukan dengan musyawarah yang nantinya menghasilkan kesepakatan. Salah satu struktur kepemimpinan masyarakat Minangkabau,yaitu kepemimpinan Tungku Tigo Sajarangan, kepemimpinan ini terdiri atas ninik mamak, alim ulama dan cadiak pandai/cendekiawan ${ }^{1}$ Salah satu struktur kepemimpinan masyarakat Minangkabau,yaitu kepemimpinan Tungku Tigo Sajarangan, kepemimpinan ini terdiri atas ninik mamak, alim ulama dan cadiak pandai/cendekiawan ${ }^{2}$ Kepemimpinan Tungku Tigo Sajaranganjuga di bagi kedalam beberapa bentuk kepemimpinan, salah satunya adalah kepemimpinan alim ulama. Kepemimpinan alim ulama merupakan kepemimpinan yang memiliki kewajiban untuk mengurus dan membimbing masyarakatnya dalam urusan ibadah agar selamat dunia akhirat sesuai dengan ajaran agama Islam ${ }^{3}$.

Dalam masyarakat Pariaman pemimpin Alim Ulama dikenal dengan sebutan Labai. Kata labai berasal dari Arab yaitu labbai yang artinya panggilan. Labai merupakan gelar adat dalam struktur sosial masyarakat Pariaman. Gelar adat labai sudah diadopsi oleh masyarakat Pariaman sejak zaman Syekh Burhanuddin mengembangkan ajaran agama Islam di Pariaman guna untuk memantapkan hubungan adat dan agama dalam struktur sosial ${ }^{4}$. Labai sama halnya dengan manti $^{5}$ di daerah lain di Minangkabau. Labai merupakan suluah bendang dalam nagari maksudnya adalah sebagai suluh/penerang bagi masyarakat nagari khususnya masyarakat yang sesuku dengan labai tersebut.

Gelar labai diberikan oleh masyarakat khususnya kepada seseorang yang dianggap mampu menjalankan kewajiban dalam bidang agama. Gelar ini bisa diberikan kepada seseorang seumur hidup, Selain itu labai juga bisa mengundurkan diri bahkan diberhentikan. Labai yang telah lanjut usia namun tidak menyerahkan gelarnya kepada masyarakat maka labai tersebut hanya bisa diganti setelah labai meninggal dunia. Labai yang belum meninggal dunia dan gelarnya telah dikembalikan kepada masyarakat maka masyarakat tetap memangil dengan gelar labai.Selain itu, Labai yang melakukan kesalahan akan dicabut gelarnya dan diberhentikan dalam menjalankan kewajibannya.

Labai yang ada di Nagari Sungai Durian berbeda dengan labai yang ada di nagari-nagari di Pariaman. Seperti di Ulakan Tapakis setiap korong memiliki 1 labai dan tidak memiliki labai suku serta labai nagari ${ }^{6}$. Sedangkan di Nagari Sungai Durian memiliki 1 labai nagari dan setiap suku juga memiliki 1 labai. Di Kecamatan Patamuan Khusunya Nagari Sungai Durian memiliki 2 gelar labai. Pertamalabai nagari, merupakan gelar yang diberikan kepada seseorang yang dia anggap mampu menjadi pemimpin alim ulama di Nagari Sungai Durian terdiri atas beberapa suku . Labai nagari ini bertangung jawab melayani seluruh masyarakat Sungai Durian dalam bidang agama. Gelar labai nagari diberikan oleh semua masyarakat Nagari Sungai Durian. Kedua labai suku, merupakan gelar yang diberikan kepada seseorang yang dianggap mampu

\footnotetext{
${ }^{1}$ Zahari Musril, 2015, Kekeliruan Hubungan Adat dengan Syarak di Minangkabau. Jakarta: Gria Media Prima. Hal: 221

2 Zahari Musril, 2015, Kekeliruan Hubungan Adat dengan Syarak di Minangkabau. Jakarta: Gria Media Prima. Hal: 221

${ }^{3}$ Zahari Musril.2015. Kekeliruan Hubungan Adat dengan Syarak di Minangkabau. Jakarta: Gria Media Prima. Hal: 171

${ }^{4}$ Hajizar. 2017. Dimensi Spiritual Nyanyian Religius Barzanji Masyarakat Bunga Tanjung Padang Panjang. Institut Seni Indonesia Padang Panjang. Hal: 20.

${ }^{5}$ Manti adalah seseorang yang ditugaskan dalam bidang agama dalam masyarakat. Koentjaraningrat. Manusia dan Kebudayaan di Indonesia. Hal:257
} 
menjadi pemimpin sukunya dalam bidang agama dan gelar inidiberikan oleh masyarakat suku masing-masing.

Setiap suku memiliki labai untuk mengurus angotanya masing-masing, namun kadang kala labai dari suku yang berbeda juga ikut terlibat dalam kegiatan keagamaan suku lainnya. Labai nagari maupun labai suku sama-sama memiliki fungsidalam masyarakat, karena labai merupakan status sosial seseorang dalam masyarakat, yang diberikan melalui gelar adat, sehingga seoranglabai harus menjalankan peranannya sesuai dengan status yang dimiliki. Status dan peran yang dijalankan labai merupakan fungsi dalam masyarakat. Salah satu fungsi labai tersebut yaitu dalam upacara kematian. Labai bertangunggung jawab menyelengarakan jenazah saat meninggal hingga 100 hari setelah meninggal.

Penelitian berkaitan dengan penelitian ini telah dilakukan oleh Sayfa Aulia Achidsti ${ }^{7}$ yang berjudul "Eksistensi Kiai dalam Pengembangan tradisi Islam di Indonesia". Penelitian berikutnya Abdullah effendi ${ }^{8}$ yang berjudul "peran dan fungsi kiai".

Penelitian ini bertujuan untuk menjelaskan fungsi labai dalam upacara kematian di Nagari Sungai Durian.Permasalahan yang akan peneliti kaji adalah tentang pemimpin tradisional di Sungai Durian yang di sebut labai. Khususnya mengakaji fungsi labai dalam upacara kematian. Labai dalam upacara kematian memiliki peran penting bagi masyarakat Nagari Sungai Durian meskipun sudah banyak ulama lainnya seperti tuangku, katik dan sebagainya. Namun dalam upacara kematian labai lebih diutamakan seperti dalam menyelengarakan jenazah harus dilakukan oleh labai.Maka dalam penelitian ini, peneliti merumuskan pertanyaan penelitian yaitu: bagaimana fungsi labai dalam upacara kematian di Nagari Sungai Durian?

Penelitian ini dianalisis dengan teori struktural fungsional yang dikemukakan oleh Radcliffe-Brown, teori ini dianggap relevan untuk melihat fungsi labai dalam upacara kematian. Dalam perspektif Radcliffe-Brown setiap individu menempati status dalam berbagai struktur masyarakat. Status dalam hal ini bukanlah prestise dari posisi individu, melainkan posisi itu sendiri. Individu yang menempati status juga memiliki hak-hak dan kewajiban tertentu yang merupakan peranan dari status tersebut ${ }^{9}$. Peranan yang dimainkan oleh individuindividu dalam kegiatan-kegiatan organisasi oleh Radcleff-Brown disebut sebagai fungsi yang bertujuan untuk membina/menjaga struktur sosial ${ }^{10}$.

\section{Metode Penelitian}

Penelitian ini dilakukan di Nagari Sungai Durian Kecamatan Patamuan Kabupaten Padang Pariaman. Labai di nagari ini berbeda dari labai di nagari lain seperti di Nagari Ulakan Tapakis. Di Nagari Ulakan Tapakis setiap Korong memiliki 1 labai sedangkan di Nagari Sungai Durian setiap Korong tidak memiliki labai melainkan di setiap suku. Selain di suku, juga ada labai lain yaitu labai nagari yang cakupannya lebih luas dari labai suku. Penelitian ini dilakukan dengan pendekatan kualitatif tipe etnografi. Teknik pengambilan informan yaitu dengan purposive sampling ${ }^{11}$. Penarikan informan penelitian dilakukan dengan sengaja dan peneliti menentukan sendiri kriteria informan penelitian yaitu orang yang terlibat relevan untuk diminta keterangannya berhubungan dengan fungsi labai dalam upacara kematian.Informan dalam penelitian ini sebanyak 24 orang yaitu 1 orang datuk, 1 orang labai nagari, 9 orang labai

\footnotetext{
${ }^{7}$ Sayfa Auliya Achidsti.2011.http://www.reseachgate.net. Eksistensi Kiai dalam Pengembangan tradisi Islam di Indonesia. Vol: 9. No:2. Hal: 214. Diakses pada tanggal 28 Juli 2018. Pukul 08:13 WIB.

${ }^{8}$ Abdullah Efendi. 2005. Eprints.ums.ac.id. Peran dan Fungsi Kiai. Tesis. Diakses pada tanggal 22 November 2018 Pukul 14:06 WIB.

${ }^{9}$ Ahmad Fedyani Sarifuddin. 2005. Antropologi Kontemporer. Jakarta. Kencana. Hal: 157

${ }^{10}$ Ahmad Fedyani Sarifuddin. 2005. Antropologi Kontemporer. Jakarta. Kencana. Hal: 157

${ }^{11}$ Burhan Bungin.2003.Data Penelitian Kualitatif. Jakarta. PT Rsaja Grafindo Persada. Hlm. 53
} 
suku, 1 orang Katik, 2 orang Tuangku, 4 orang Ninik Mamak, 1 orang Kapalo Mudo, 2 urang siyak dan 3 orang anggota masyarakat yang yang melakukan upacara kematian.

Teknik pengumpulan data yang dilakukan penelitian ini adalah dengan menggunakan observasi partisipasi, wawancara mendalam, dan dokumentasi ${ }^{12}$.Jenis observasi dalam penelitian ini adalah observasi aktif, dimana peneliti terlibat langsung didalam objek penelitian. Observasi aktif, sewaktu pengumpulan data peneliti mengikuti semua kegiatan upacara kematian di rumah duka. Wawancara yang dilakukan peneliti adalah wawancara mendalam (Indeptinterview). Wawancara mendalam dilakukan kepada setiap informan yang dipilih dalam puposive sampling, pertanyaan yang diberikan kepada informan sesuai dengan pedoman wawancara yang telah disediakan dengan poin-poin wawancara. Poin-poin wawancara tersebut dikembangkan lagi dalam bentuk pertanyaan-pertanyaan yang terkait dengan fungsi labai dalam upacara kematian di Nagari Sungai Durian

Untuk melengkapi data dokumentasi dilakukan dengan mengambil foto-foto, merekam suara dan video, catatan harian observasi dan catatan harian wawancara terkait dengan fungsi labai dalam upacara kematian di Nagari Sungai Durian. Untuk menguji keabsahan data peneliti menggunakan teknik triangulasi data. Jenis triangulasi yang digunakan dalam penelitian ini yaitu triangulasi sumber. Data yang diperoleh di lapangan dianalisis mengacu pada model analisisJames Spardley ${ }^{13}$ analisis tema budaya (cultural themes).

\section{Fungsi Labai Dalam Upacara Kematian}

Upacara kematian adalah persembahan terakhir untuk anggota masyarakat yang meninggal. Setiap anggota masyarakat yang meninggal selalu dilakukan upacara sebagai tanda penghormatan terakhir terhadap anggota keluarga yang meninggal. Begitu juga pada masyarakat Nagari Sungai Durian juga melakukan upacara terhadap anggota masyarakat yang meninggal. Untuk melakukan upacara tersebut membutuhkan labai. Oleh sebab itu, labai memiliki fungsi dalam upacara kematian. Dibawah ini akan di jelaskan fungsi labai dalam upacara kematian:

\section{Labai Nagari}

\section{Menyampaikan pesan duka kepada labai-labai suku}

Sebagai seorang yang dianggap pemimpin dalam masyarakat maka jika terjadi peristiwa yang berkaitan dengan agama maka labai harus mengetahuinya terlebih dahulu. Seperti dalam kematian, jika ada salah satu anggota meninggal maka labai suku akan menyampaikan pesan duka kepada labai nagari. Labai nagari akan menyampaikan pesan duka itu kembali kepada labai-labai suku lainnya yang ada di Sungai Durian dan Labai nagari yang mengajak labai suku untuk pergi melayat.

\section{Memimpin proses Mancabiak kain kafan}

Sebagai seorang yang dianggap pemimpin dalam upacara kematian ketika memulai mancabiak kain kafan maka harus didahului oleh labai nagari karena ada do'a-doa yang harus dibaca sebelum mancabiak kain kafan. Jika labai nagari belum datang maka mancabiak kain kafan belum bisa dimulai.

\section{Memimpin proses pemandian jenazah}

Kewajiban ini dilaksanakan oleh labai nagari karena labai nagari terikat oleh sumpah dan janji sebelum labai tersebut diberi gelar/dinobatkan menjadi labai. Untuk penyiraman air pertama kepada jenazah harus dilakukan oleh labai. Labai yang akan menekan perut jenazah

\footnotetext{
${ }^{12}$ Lexy. J. Moleong. 2009. Moleong. Metode Penelitian Kualitatif. Bandung:Remaja Rosdakarya.

${ }^{13}$ James P Spadley. 1997. Metode Etnografi. Yogyakarta:Tiara Kencana Yoga. Hal:181
} 
agar mengeluarkan hadas besar. Dalam memandikan jenazah kain kafan yang dicabiak sebelumnya hanya boleh digunakan oleh labai.

\section{Mambuang Aie Sambilan (Membuang Air Sembilan)}

Aie sambilan adalah air yang diletakan dalam dalam 9 gelas. Sesuai kepercayaan masyarakat Sungai Durian dilahir/fakta hanya terlihat air dalam sembilan gelas akan tetapi secara batin artinya adalah 9 buah sungai. Sungai tersebut akan diseberangi oleh roh jenazah yang meninggal. Salah satu air tersebut berada dalam gelas yang agak besar dan air yang lebih banyak dari gelas lainya. ${ }^{14}$ Air dalam gelas yang lebih besar merupakan sungai terakhir yang diseberangi oleh roh jenazah, sehingga setelah roh jenazah tidak bisa menyeberangi sungai kembali ${ }^{15}$.Setelah labai mewhudukkan jenazah, labai mambuang aie sambilan Aie sambilan mulai dari badan sampai ke kaki. Setiap hendak membuang air dalam gelas tersebut labai membaca do'a terlebih dahulu. Untuk gelas yang lebih besar dibuang oleh labai ke tubuh jenazah terakhir kali.

\section{Mengafani jenazah}

Mengakafani jenazah merupakan menutupi atau membungkus jenazah dengan kain putih yang dapat menutupi tubuh jenazah. Mengafani jenazah wajib dilakukan oleh labainagari. Labai nagari menutup wajah jenazah dengan kapas dan memasangkan deta di kepala jenazah lalu membungkus jenazah dan mengikat jenazah dengan tali yang sudah disediakan dari kain kafan.

\section{Mensholatkan jenazah}

Sholat jenazah adalah sholat yang dilakukan untuk jenazah muslim. Labai nagari harus mengajak keluarga kerabat dekat dan kerabat jauh untuk ikut mensholatkan jenazah tersebut. Ketika mensholatkan jenazah labai nagari harus berada pada bagian depan meskipun dalam Islam tidak mengatur tempat berdirinya seseorang dalam melakukan sholat jenazah. Akan tetapi sebagai seorang pemimpin, labai menenpati barisan depan. Pada saat sholat jenazah labai nagari meminta imam nagari untuk mengimani sholat jenazah namun posisi labai nagari berada dibarisan depan tepatnya dibelakang imam.

\section{Memandu Pemakaman Jenazah}

Labai nagari memimpin pemakaman jenazah, labai nagari memastikan apakah jenazah telah menghadap kiblat atau belum serta labai nagari memastikan apakah tali pocong jenazah sudah dibuka atau belum serta memastikan wajah sudah menyentuh tanah atau belum. Selanjutnya labai juga memberikan tali di kaki dan telingga jenazah untuk memudahkan labai memberi tanda pudiang nantinya setelah pemakaman selesai. Puding tersebut ditanamkan tepat di kaki dan telingga jenazah. Tanda ini harus diperhatikan baik-baik oleh labai agar tidak salah memberi tanda. Tanda ini berguna bagi labai suku untuk melakukan manalakin.

\section{Labai Suku}

Labai suku memiliki fungsi tertentu dalam masyarakat sukunya. Salah satunya dalam upacara kematian. Fungsi labai suku dalam upacara kematian adalah:

\section{Mengabarkan berita kepada labai nagari}

Sebagai seorang yang dianggap pemimpin dalam suku, peristiwa-peristiwa yang terjadi dalam masyarakat lebih diketahui oleh labai suku dibandingkan dengan pemimpin lainnya. Lalu labai sukulah yang menyampaikan pesan duka tersebut ini kepada labai nagari. 


\section{Memananti labai}

Sebagai pemimpin dalam masyarakat labai suku memiliki peran penting dalam masyarakat Sungai Durian yaitu mananti labai. labai suku harus datang lebih awal ke rumah duka karena labai yang akan menyambut dan menyalami labai nagari dan labai suku lainnya. Jika labai suku belum datang maka labai nagari dan labai suku lainya tidak akan memasuki rumah duka untuk memulai prosesi upacara kematian.

\section{Membantu labai nagari mancabiak kain kafan}

Labai suku ikut membantu labaidalam mancabiak kain kafan jenazah. labai suku duduk melingkar bersama dan membantu labai nagari untuk memastikan kain kafan yang akan digunakan untuk jenazah harus bersih tanpa kotoran. Selain itu labai suku juga melipat dan menggulung kain kafan yang telah dirobek oleh labai nagari.

\section{Memberi Kata PembukaTahlie (tahlilan)}

Tahlilan adalah membaca kalimatlailaha ilallah sebanyak 7 ribu kali yang dilakukan ketika jenazah sedang dimandikan dan dikafani. Tahlie ini paling sedikit dilakukan sebanyak 7 orang. labai melakukan tahlie sebanyak 9 orang. Tahlie yang dilakukan saat itu dipimpin oleh imam nagari. Walaupun tahlie tersebut dipimpin oleh imam nagari jika tidak atas izin labai suku maka imam nagari tidak boleh dan tidak menjadi pemimpin tahlie. Selain itu, walaupun pemimpin tahlie dipimpin oleh imam nagari untuk pembukaan tahlie atau pasambahan harus dilakukan oleh labai suku yang meninggal. Sebelum melakukan tahlie adanya petatah petitih yang disampaikan labai suku kepada pemimpin tahlie. Inti dari petatah petitih tersebut adalah mengenai jenazah agar terhindar dari siksaan kubur sertameminta imam nagari menjadi pemimpin tahlie. Jika imam nagari tidak ada maka yang memimpin tahlie adalah labai suku itu sendiri.Setelah melakukanpetatah petitih labai beserta pemimpin memulai tahlie tersebut menggunakan basabah (tasbih) dan batu. Setiap satu lingkaran basabah, pemimpin tahlie menjatuhkan 1 buah batu ke talam. Artinya jika 1 buah batu jatuh ke talam maka masingmasing orang telah membaca kalimah lailaha ilallah sebanyak 78 kali.

\section{Sholat jenazah}

Labai suku harus ikut mensholatkan jenazah dan labai suku juga mengajak kerabat yang meninggal serta kaumnya untuk melaksanakan sholat jenazah. Sebagai seorang pemimpin maka labai suku yang memberi instruksi kepada kerabat dan kaumnya untuk mengambil wudhu. Ketika labai telah memastikan labai nagari selesai menggafani jenazah maka labai suku berkata kepada kerabat dan kaumnya manyauk aie lai masyarakat sudah tahu sendiri bahwa labai akan mensholatkan jenazah maka masyarakat akan mengambil wudhu.

\section{Manalakin manimpo}

Manalakin manimpo adalah proses membangunkan jenazah kembali dan mengajarkan jenazah agar mampu menjawab pertanyaan-pertanyaan malaikat di kubur. Karena sesuai kepercayaan masyarakat Sungai Durian setelah jenazah dimakamkan maka malaikat akan mendatangi jenazah untuk menanyakan lima pertanyaan yaitu tuhan,agama, nabi, kitab dan kiblat. Oleh sebab itu, menurut kepercayaan masyarakat Sungai Durian sebelum malaikat mendatangi jenazah maka jenzah dibangunkan terlebih dahulu oleh labai suku dan diajarkan menjawab pertanyaan malaikat. Untuk melakukan manalakin manimpo ini labai suku harus memegang tanda yang telah diberi labai nagari yaitu pudiang. Pudiang tersebut diletakkan labai nagari tepat pada kaki dan telingga jenazah. Labai suku memegang tanda pudiang di telingga jenazah dan membacakan do'a-doa. Mengapa demikian daun puding sebagai tanda makam tersebut dipegang? Karena, supaya jenazah mendengar apa yang disampaikan oleh labai suku. inti yang disampaikan labai suku tersebut adalah hai "si A anak si B dan si C binti 
B. nanti akan ada malaikat yang akan datang bertanya kepadamu. Jika malaikat bertanya siapa Tuhanmu? Maka jawablah Allah. Jika malaikat bertanya apa agamamu maka jawablah Islam. Jika malaikat bertanya siapa Nabimu maka jawablah Muhamad Saw. Jika malaikat bertanya apa kitabmu maka jawablah Al-qur'an. Jika malaikat bertanya kemana kiblatmu maka jawablah ka'bah".

\section{Manalakin tujuah hari (doa tujuh hari)}

Manalakin tujuah hari adalah mendoakan jenazah selama 7 hari. Manalakin tujuah hari ini dilakukan setiap pagi setelah sholat subuh dan sore sesudah sholat ashar. Makanalakin tujuah hari ini bertujuan agar jenazah terhindar dari siksaan kubur karena sesuai kepercayaan masyarakat Sungai Durian setiap hari selama 7 hari jenazah di dalam kubur mendapatkan azab. Azab yang didapatkan jenazah di dalam kubur pada hari pertama adalah jenazah merasakan gelap, kedua jenazah merasa terasa kaciak,ketiga jenazah merasa panas, keempat jenazah merasa dingin, kelimajenazah merasa busuk, keenam terasa haus, ketujuh jenazah merasa lapar. Agar terhindar dari azab kubur maka labai suku yang akan melakukan talakin selama 7 hari berturut-turut pagi selesai sholat subuh dan sore selesai sholat ashar. Manalakin ini terkadang dilakukan labai di makam jenazah terkadang dilakukan di rumah labai. Namun supaya doa talakin tersebut sampai kepada jenazah lebih baik dilakukan dimakam dengan memegang pudiang yang ada dimakam jenazah.

\section{Memberi Kata Pembuka dalam Maniigo Hari, Manujuah Hari, Maampek Puluah Hari dan Manyaratuih Hari}

Ketika hendak memulai acara maka harus dibuka oleh labai suku terlebih dahulu karena adanya petatah petitih yang disampaikan labai suku sebelum memulai acara tersebut danmeminta tuangku atau imam nagari menjadi pemimpin melakukan upacara kematian tersebut. Jika tidak ada tuangku maka yang akan menjadi pemimpin dalam upacara kematian ini adalah labai suku itu sendiri. Selain itu jika upacara sudah selesai maka labai suku akan memberikan hak atau biasa disebut sedekah kepada labai-labaidan tuangku yang melakukan upacara tersebut.

\section{Yang Diterima Labai}

Labai jika telah menjalankan kewajibannya maka labai akan menerima haknya yang biasa disebut masyarakat sedekah. Yang biasa diterima labai diantaranya adalah:

\section{Uang}

Labai jika telah menjalankan kewajiban maka labia akan menerima uang. masyarakat biasanya menyebut dengan sedekah. Uang ini akan diterima oleh labai pada waktu labai selesai menjalanakan kewajibanya. Jumlah nilai uang sedekah tidak ditentukan.

\section{Bantal, Kasur Dan Kain Sarung}

Bantal, kasur dan kain sarung diberikan kepada labai yang melakukan manalakin manimpo dan manalakin tujuah hari. Hal ini dilakukan masyarakat karena masyarakat telah memahami aturan struktur sosial yang telah diikuti dari nenek moyang mereka.

\section{Kain Kafan, Kain Panjang, Kapas Dan Sabun}

Kain kafan, kain panjang, kapas dan sabun hanya diberikan kepada labai nagari.

\section{Analisa Fungsi Labai dengan Struktur Fungsional Radcliffe-Brown.}

Perspektif Radcliffe Brown setiap individu memiliki status dan peranan dalam struktur sosial masyarakat. labai adalah sebuah status dalam masyarakat Sungai Durian yang memiliki 
peran-peran tertentu dalam masyarakat Nagari Sungai Durian. Struktursosial adalah pola nyata hubungan atau interaksi antara berbagai komponen masyarakat pola-pola yang secara relative bertahan lama karena interaksi-interaksi tersebut terjadi dalam cara yang kurang-lebih teroganisir. Dalam struktur sosial masyarakat Sungai Durian, labai nagari dengan labai suku lainnya menjalankan hubungan atau interaksi yang terus bertahan hingga sekarang. Hubungan tersebut bertahan karena sudah teroganisir denagan baik dalam struktur sosial masyarakat Sungai Durian.

Kontribusi yang dimainkan oleh item sosial atau sebuah institusi sosial terhadap kemantapan suatu struktur sosial disebut sebagai fungsi. Dalam hal ini fungsi diartikan dalam sebagai peranan kegiatan-kegiatan dalam membina/menjaga struktur atau kesesuaian antara efek dari kegiatan dan kebutuhan dari struktur organisasi. Peranan dalam upacara kematian yang dijalankan labai di Nagari Sungai Durian disebut sebagi fungsi oleh Radcliffe Brown yang bertujuan untuk membina/menjaga struktur atau kesesuaian antara efek dari kegiatan dan kebutuhan dari struktur sosial masyarakat Sungai Durian.

\section{Kesimpulan}

Labai berfungsi dalam upacara kematian bagi masyarakat Sungai Durian. Fungsi tersebut bertujuan untuk menjaga/membina struktur atau kesesuaian antara efek dari kegiatan dan kebutuhan dari struktur sosial masyarakat Sungai Durian.

Peranan yang dijalankan oleh labai disebut oleh Radcliffe-Brown sebagai fungsi. Fungsi tersebut dilihat secara emik dari labai yaitu: menyampakan pesan duka, memimpin proses mancabiak kain kafan, memimpin proses pemandian jenazah, mambuang aie sambilan, mengafani jenazah, mensholatkan jenazah, memandu proses pemakaman jenazah, menyambut labai, membantu labai nagari mancabiak kain kafan, membuka tahlie dan melakukan petatah petitih, manalakin manimpo, dan Manalakin tujuah hari .

\section{Daftar Pustaka}

Abdullah Efendi. (2005). Eprints.ums.ac.id. Peran dan Fungsi Kiai. Tesis.

Ahmad Fedyani Sarifuddin. (2005). Antropologi Kontemporer. Jakarta. Kencana.

Burhan Bungin. (2003). Data Penelitian Kualitatif. Jakarta. PT Rsaja Grafindo Persada. Hajizar. (2017). Dimensi Spiritual Nyanyian Religius Barzanji Masyarakat Bunga Tanjung Padang Panjang. Institut Seni Indonesia Padang Panjang.

James P Spadley. (1997). Metode Etnografi. Yogyakarta:Tiara Kencana Yoga.

Koentjaraningrat. (2005). Pengantar Antropologi .Jakarta. UI Press

Lexy. J. Moleong. (2009). Metode Penelitian Kualitatif. Bandung:Remaja Rosdakarya

Sayfa Auliya Achidsti. (2011). http://www.reseachgate.net. Eksistensi Kiai dalam Pengembangan tradisi Islam di Indonesia. Vol: 9. No:2. Hal: 214.

Zahari Musril. (2015). Kekeliruan Hubungan Adat dengan Syarak di Minangkabau. Jakarta: Gria Media Prima. 